\title{
Facies arrangement and cyclostratigraphic architecture of the Templet Member and the Kapp Starostin Formation (Permian) on Spitsbergen, Svalbard
}

\author{
Elham Jafarian', Ralph Dirk Groen ', Casimir W. Nooitgedacht ${ }^{1,2}$, Christian Scheibner ${ }^{3}$, \\ Dierk Blomeier ${ }^{4,5}$ \& John J.G. Reijmer ${ }^{1,2}$
}

${ }^{1}$ Vrije Universiteit Amsterdam, Faculty of Earth and Life Sciences, Sedimentology and Marine Geology Group, De Boelelaan 1085, 1081 HV Amsterdam, The Netherlands.

${ }^{2}$ College of Petroleum Engineering \& Geosciences, King Fahd University of Petroleum \& Minerals, Dhahran 31261, Saudi-Arabia.

${ }^{3}$ Universität Bremen, Geowissenschaften, FB 5, Postfach 330440, D 28334 Bremen.

${ }^{4}$ Norwegian Polar Institute, Geo Department, FRAM Centre, N-9296 Tromsø, Norway.

${ }^{5}$ Millennia Stratigraphic Consultants, United Kingdom and Germany.

E-mail corresponding authors Elham Jafarian:e.jafarian@vu.nl/ John J.G.Reijmer: reijmer@kfupm.edu.sa

Because of outstanding outcrops, Spitsbergen (Svalbard archipelago) provides unique opportunities to investigate the whole Upper Palaeozoic succession in great detail. This study can help to interpret the stratigraphic history and depositional evolution at other locations exposing coeval shelf strata along the northern margin of Pangea, e.g., the southern Barents Sea and Arctic Canada. Bed-scale outcrop observations are combined with microfacies studies to interpret the sedimentary settings and depositional environment of the Upper Palaeozoic strata. A sequencestratigraphic analysis has been carried out to evaluate the relative timing of sediment facies deposition in response to sea-level changes. The Early Artinskian to Kazanian successions of the Templet Member and the Kapp Starostin Formation were divided into five parasequences that are superimposed on a long-term, second-order, sea-level fall. These parasequences record a fundamental change of the sedimentary setting, from a restricted-marine, warm-water carbonate platform to an open-marine, cold-water, biosiliceous-carbonate ramp system. A cross-section across Svalbard comprising nine onshore sections shows that during deposition of the Kapp Starostin Formation a major depocentre marked by thick parasequences and a higher proportion of deep-water facies (bedded cherts) is located in the southwest of Spitsbergen (at Akseløya), whereas northeastern Svalbard records shallow-water microfacies. Svalbard was tectonically passive during the Permian; the local differences in accommodation space and facies were most likely linked to the rejuvenation of pre-existing structural elements, inherited from the Carboniferous. A deepening of the depositional environment combined with cold-water climatic conditions as recorded in our study area has also been documented in other Upper Palaeozoic successions around the Arctic, such as the Finnmark Platform (Norwegian Barents Sea) and the Sverdrup Basin (Arctic Canada). This transition in the depositional environment along the northern margin of Pangea is the result of large-scale changes in oceanic circulation patterns and local palaeogeographic changes during the northward movement of Pangea.

Keywords: Permian; Svalbard (Spitsbergen); Spiculitic chert; Carbonates; Stratigraphy; Depositional environment

Received 4. May 2017 / Accepted 6. October 2017 / Published online 4. December 2017

\section{Introduction}

The Permian was a dynamic period in Earth history because it was then that the supercontinent Pangea formed; an event that affected many global processes including tectonics, climate and ocean circulation
(Ziegler et al., 1997; Laya \& Tucker, 2012). The Franklinian shelf, located on the northern rim of the supercontinent Pangea, preceded the formation of basins in Arctic Canada (the Sverdrup Basin), the Barents Sea (the Finnmark Platform, the Hammerfest Basin and onshore Svalbard), Greenland (the Wandel

Jafarian, E., Groen, R.D., Nooitgedacht, C.W., Scheibner, C., Blomeier, D. \& Reijmer, J.J.G. 2017: Facies arrangement and cyclostratigraphic architecture of the Templet Member and the Kapp Starostin Formation (Permian) on Spitsbergen, Svalbard. Norwegian Journal of Geology 97 , 263-281. https://dx.doi.org/10.17850/njg97-4-02. 
Sea Basin), and Russia (the Timan-Pechora Basin) (Scotese \& Langford, 1995; Golonka, 2002). During the Late Palaeozoic, the sediments within these basins recorded a gradual cooling from warm and arid to cold-water conditions and an associated deepening of the depositional environments (Steel \& Worsley, 1984; Beauchamp, 1994; Beauchamp \& Desrochers, 1997; Ehrenberg et al., 1998).

This study focuses on the Barents shelf, which consists of a complex series of basins, platforms and highs (e.g., Anell et al., 2014). The Svalbard archipelago is situated between $74^{\circ}$ and $81^{\circ} \mathrm{N}$ latitude and $10^{\circ}$ and $35^{\circ} \mathrm{E}$ longitude, high above the Arctic Circle in the northwestern part of the Barents Shelf (Fig. 1A) (Johannessen \& Steel, 1992; Dallmann et al., 1999; Jafarian et al., 2017). Spitsbergen is the main island of Svalbard and is host to many outstanding outcrops of the entire Upper Palaeozoic succession including carbonates and biosiliceous sedimentary rocks (Fig. 1A). We summarise the stratigraphy of three onshore sections that range in age from the Early Artinskian to Kazanian (Early to Late Permian). The logs cover the uppermost part of the Gipsdalen Group (Templet Member) and the succeeding Tempelfjorden Group on central Spitsbergen. The measured sections are compared with four sections in NE Svalbard (Blomeier et al., 2011, 2013) and two sections in central and SW Spitsbergen (Ehrenberg et al., 2001). Combining the results of this study and previous studies we aim to produce a comprehensive sequencestratigraphic model, covering the larger part of the archipelago. This will provide a better understanding of the spatial and temporal microfacies distribution and the depositional morphology and development. These findings can help to improve the interpretation of similar systems in the geological record.

Studies have shown that biosiliceous sediments are a potentially good source and reservoir rocks for hydrocarbons (e.g., Surdam \& Stanley, 1981; Rogers \& Longman, 2001). The Permian was a time of extensive spiculitic chert accumulation along the northern margin of Pangea, and several seismic-based sequencestratigraphic studies have resulted in findings of reservoir rocks for hydrocarbon exploitation, e.g., the Finnmark Platform (Norwegian Barents Sea) (Ehrenberg et al., 1998, 2001; Beauchamp \& Baud, 2002; Larssen et al., 2002; Gates et al., 2004; Colpaert et al., 2007). Therefore, the study presented here will be of benefit to our understanding of the depositional environment and bedscale, lateral and vertical, microfacies variations in the source and reservoir rocks of the Barents Sea oil and gas plays. Furthermore, synthetic seismograms, which could be constructed based on the facies variations within a well-defined sequence-stratigraphic framework, and associated petrophysical properties (Jafarian et al., 2017) will provide useful analogues for subsurface equivalents (Jafarian et al., in press).

\section{Study interval}

The Upper Palaeozoic succession of Spitsbergen contains two main lithostratigraphic units, the Lower Carboniferous to Lower Permian Gipsdalen Group and the Early to Late Permian Tempelfjorden Group (Fig. 1B).

The Gipshuken Formation (Sakmarian-Artinskian) is the upper formation of the Gipsdalen Group and is exposed over the whole archipelago except for the southernmost part of Spitsbergen (Sørkapp-Hornsund High) (Blomeier et al., 2009). In central Spitsbergen, the uppermost part of the Gipshuken Formation is marked by the deposition of evaporite/carbonate cycles of the Templet Member representing restricted, peritidal platform and sabkha environments (Dallmann et al., 1999). In the Early Permian (Artinskian), evidence of subaerial exposure, intense karstification and the collapse of the Gipshuken Platform implies a significant regression. The latter ultimately produced a hiatus in sedimentation separating the Gipsdalen and Tempelfjorden groups (Fig. 1B) (Ehrenberg et al., 2001; Groen, 2010). According to Blomeier et al. (2011), this hiatus represents a period between 1 and 9 Myr, but this may vary locally.

The overlying Tempelfjorden Group contains the Kapp Starostin Formation (Late Artinskian-Kazanian/ Earliest Tatarian) in central and northern Spitsbergen (Fig. 1B). In east Svalbard, the Tempelfjorden Group consists of the Tokrossøya Formation at Hornsund and the Miseryfjellet Formation on Bjørnøya (Cutbill \& Challinor, 1965; Dallmann et al., 1999). The Vøringen Member, Late Artinskian to Kungurian, is the oldest member of the Kapp Starostin Formation and occurs in most areas of Spitsbergen except on Brøggerhalvøya in the northwest of the island (Dallmann et al., 1999). The member contains coarse-grained, bioclastic limestones deposited on the shoreface in storm-dominated ramp settings (Dallmann et al., 1999; Blomeier et al., 2011). Deposits covering the Vøringen Member include dark to light-coloured, spiculitic chert horizons with shale partings (Groen, 2010; Blomeier et al., 2011). In central Spitsbergen, the Stensiöfjellet Member forms the uppermost strata of the Kapp Starostin Formation and consists of green, glauconitic sandstones (with up to 30\% glauconite) and spiculitic cherts deposited in a nearshore environment (Fig. 1B) (Dallmann et al., 1999). The transition from the Tempelfjorden Group to the overlying Sassendalen Group is marked by a sharp change to marine siliciclastics. It also marks the termination of the deposition of biota-dominated sediments, e.g., spiculitic cherts and bioclastic limestones (Ehrenberg et al., 2001; Blomeier et al., 2011). No evidence of subaerial exposure or a hiatus has been recorded in central Spitsbergen (Mangerud \& Konieczny, 1993). However, whether or not the Permo-Triassic boundary represents a period of 


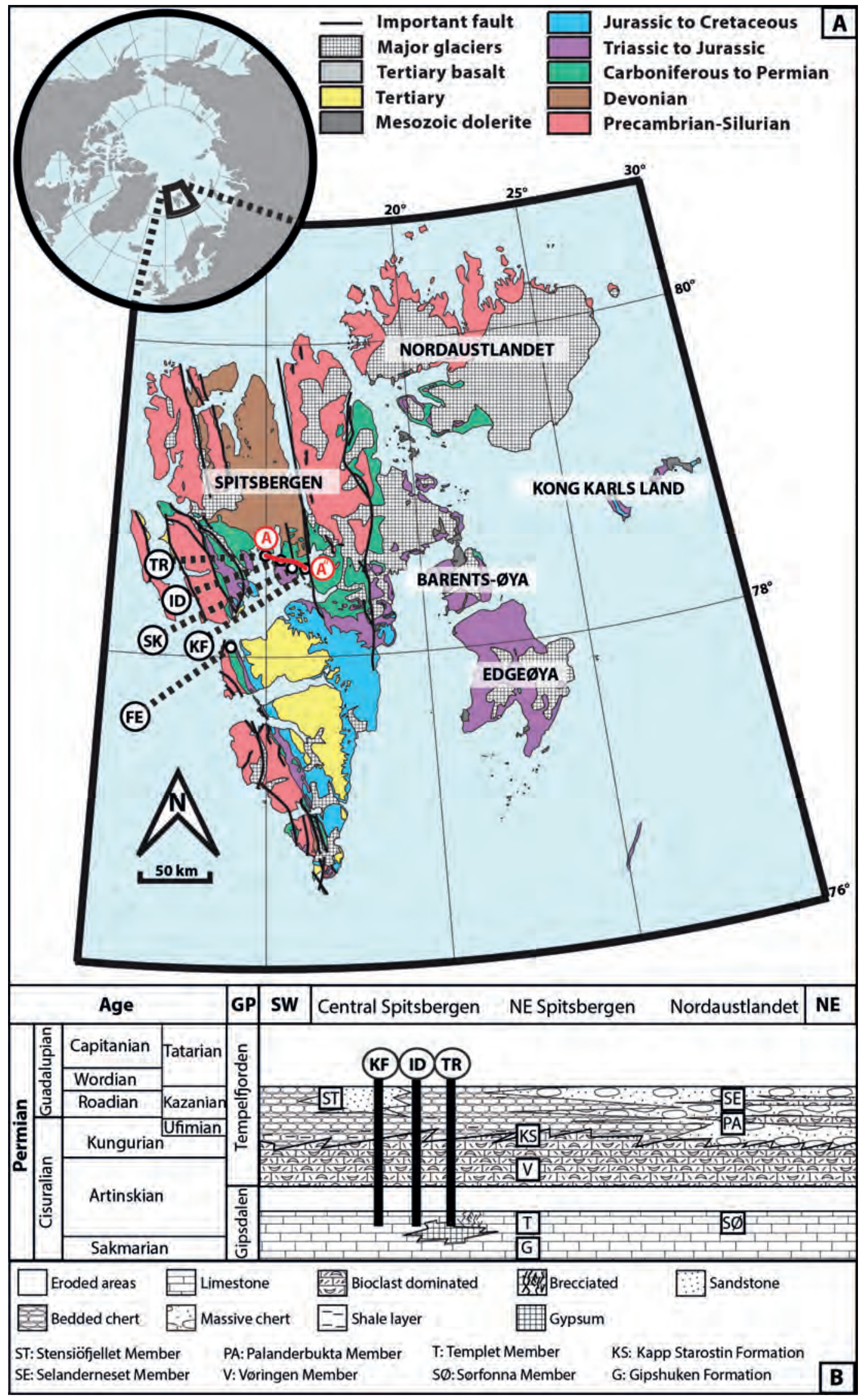

Figure 1. Geological map of the Svalbard archipelago. Strata investigated for this study are of Permian age and are represented by the greenshaded areas on the map and in the legend. Sections location indicated: Tålmodryggen (TR); Idodalen (ID); Skansen (SK); Kapp Fleur de Lys (KF) and Festningen (FE). A-A" indicates cross-sections used for the correlation profile in figure 5 (modified from http: //npolar.no/geonet/ items general/frame.html). (B) Chronostratigraphic framework and main lithologies of the Permian of Svalbard (adapted from Dallmann et al., 1999). The stratigraphic positions of the investigated sections are indicated: Tålmodryggen (TR), Idodalen (ID) and Kapp Fleur de Lys (KF). 
erosion, non-deposition or conformable sedimentation remains controversial (Mørk et al., 1989; Stemmerik \& Worsley, 1989; Mangerud \& Konieczny, 1993; Ehrenberg et al., 2001; Nakrem et al., 2008; Dustira et al., 2013).

\section{Methods}

Three sections were logged in central Spitsbergen at selected locations: (i) section KF located at Kapp Fleur de Lys, on the western coast of Billefjorden; (ii) section ID positioned at Idodalen, on the eastern coast of Dicksonfjorden, and (iii) section TR located at Tålmodryggen, on the western coast of Dicksonfjorden.

The sedimentological sections were logged measuring layer thicknesses and defining colour, lithology, texture (Dunham, 1962), components, sedimentary structures and key stratigraphic surfaces. These data are supplemented with some samples from the type-section of the Kapp Starostin Formation at Festningen (FE) (Outer Isfjorden) and data from a section at Skansen (SK) (western coast of Billefjorden) (Blomeier et al., 2011, 2013).

Thermogravimetric analysis (TGA) was performed on selected samples to determine the amount of organic matter, carbonate and non-carbonate residue (Dean, 1974; Earnest, 1984).

A total of 111 thin-sections (Idodalen: $\mathrm{n}=35$, Kapp Fleur de Lys: $\mathrm{n}=21$, Tålmodryggen: $\mathrm{n}=37$, Festningen: $\mathrm{n}=10$, and Skansen: $\mathrm{n}=8), 2 \times 5 \mathrm{~cm}$ size, were prepared for petrographic analysis. The siliciclastics were categorised following the grain-size based classification of Wentworth (1922), and carbonates were classified according to Dunham (1962). Biosiliceous sedimentary rocks were defined based on the main components and characteristic fabrics. In total, fourteen microfacies types have been identified of which the detailed information is listed in Table 1. The interpretation of the microfacies environment was used to determine variations in relative sea level, and it also provided the basis for a correlation between the individual sections and the construction of a sequence-stratigraphic framework.

\section{Results}

\section{Microfacies analysis}

Previous work on the Svalbard exposures (Ehrenberg et al., 1998, 2001; Hüneke et al., 2001; Blomeier et al., 2011, 2013; Buggisch et al., 2012) consisted of highly detailed logging, facies descriptions and geochemical analyses. The microfacies studies discussed in these earlier studies are used as a basis for the definition and identification of the microfacies types presented in this study. During the fieldwork, three new sections at Kapp Fleur de Lys (KF), Idodalen (ID) and Tålmodryggen (TR) were investigated enclosing all previously encountered microfacies types. A total of fourteen microfacies types has been defined based on lithology, texture, components and sedimentary structures (Fig. 2; Table 1). Each microfacies is linked to specific depositional processes and settings. Evaporites $($ MFT-1; $\mathrm{n}=2)$, microbial limestones (MFT-2; $\mathrm{n}=$ 7), mudstones (MFT-3; $\mathrm{n}=5$ ), peloidal, bioclastic wacke- to packstones (MFT-4; $\mathrm{n}=1$ ), Microcodiumbearing sediments (MFT-5; $\mathrm{n}=2)$ and lithoclastic rudstones (carbonate breccias) (MFT-6; $\mathrm{n}=3$ ) occur predominantly in the Templet Member. Coarse-grained, brachiopod limestones (MFT-7; $n=5$ ), coarse-grained, mixed-bioclastic limestones (MFT-8; $\mathrm{n}=7$ ) and finegrained, mixed-bioclastic limestones (MFT-9; $\mathrm{n}=9$ ) are restricted to the strata of the Vøringen Member. Coarse-grained, bryozoan limestones (MFT-10; $\mathrm{n}=15$ ) and coarse-grained, echinoderm limestones (MFT-11; $\mathrm{n}=2$ ) are present within the Kapp Starostin Formation. Spiculites (MFT-12; $\mathrm{n}=50$ ), locally interbedded with thin horizons of shale (MFT-13; $\mathrm{n}=1$ ), are a dominant microfacies within the Kapp Starostin Formation. In addition, glauconitic calcareous sandstones (MFT-14; $\mathrm{n}=2$ ) are a typical microfacies within the Stensiöfjellet Member.

Thermogravimetric analysis (TGA) shows that carbonate content decreases when moving from the microfacies of the Templet Member to the Kapp Starostin Formation. At the same time, the biogenic silica (spicule) content increases (Jafarian et al., 2017).

\section{Section descriptions}

\section{Kapp Fleur de Lys section (KF)}

The section at Kapp Fleur de Lys (Fig. 1) is 139 m thick and encloses the upper $2 \mathrm{~m}$ of the Templet Member and $137 \mathrm{~m}$ of the overlying Kapp Starostin Formation. The latter formation includes a $7.5 \mathrm{~m}$-thick Vøringen Member at its base and a $17 \mathrm{~m}$-thick Stensiöfjellet Member at the top.

The Templet Member consists of grey-coloured, micritic limestones (MFTs-2, $3 \& 4$ ) followed by medium-bedded, lithoclastic rudstones (MFT-6) and Microcodium bearing sediments (MFT-5). In this section, the boundary between the Templet and Vøringen Members is not exposed. The Vøringen Member is characterised by a series of 2-3 m-thick beds of fossiliferous limestones (Groen, 2010; Blomeier et al., 2013). The coarse-grained, brachiopod limestones (MFT-7) grade into finingupward horizons (graded bedding) with various other biota such as echinoderms and bryozoans (MFTs-8, 9). Local bioturbation by Skolithos burrows has ostensibly led to silicification. Above this member, a monotonous series of thin- to medium-bedded cherts (MFT-12) 

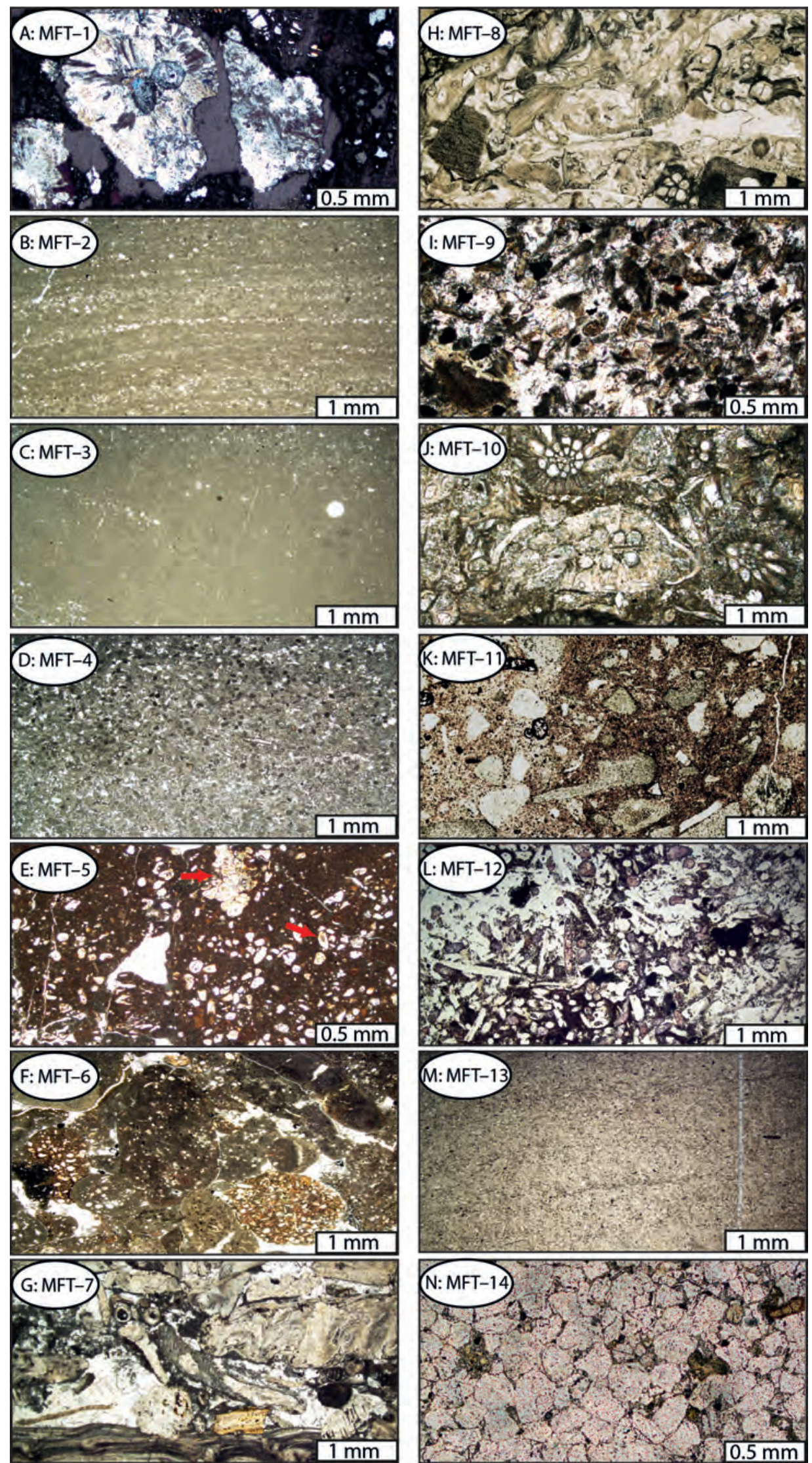

Figure 2. Thin-section photographs of each microfacies type. Scales indicated. (A) MFT-1: evaporite; (B) MFT-2: microbial limestone; (C) MFT-3: mudstone; (D) MFT-4: peloidal bioclastic wacke- to packstone; (E) MFT-5: Microcodium-bearing sediments (Microcodium aggregate and single crystal are indicated by arrows); (F) MFT-6: lithoclastic rudstone (breccia); (G) MFT-7: coarse-grained, brachiopod limestone; (H) MFT-8: coarse-grained, mixed-bioclastic limestone; (I) MFT-9: fine-grained, mixed-bioclastic limestone; (J) MFT-10: coarse-grained, bryozoan limestone; (K) MFT-11: coarse-grained, echinoderm limestone; (L) MFT-12: spiculite; (M) MFT-13: clay-siltstone; (N) MFT-14: glauconitic calcareous sandstone. 


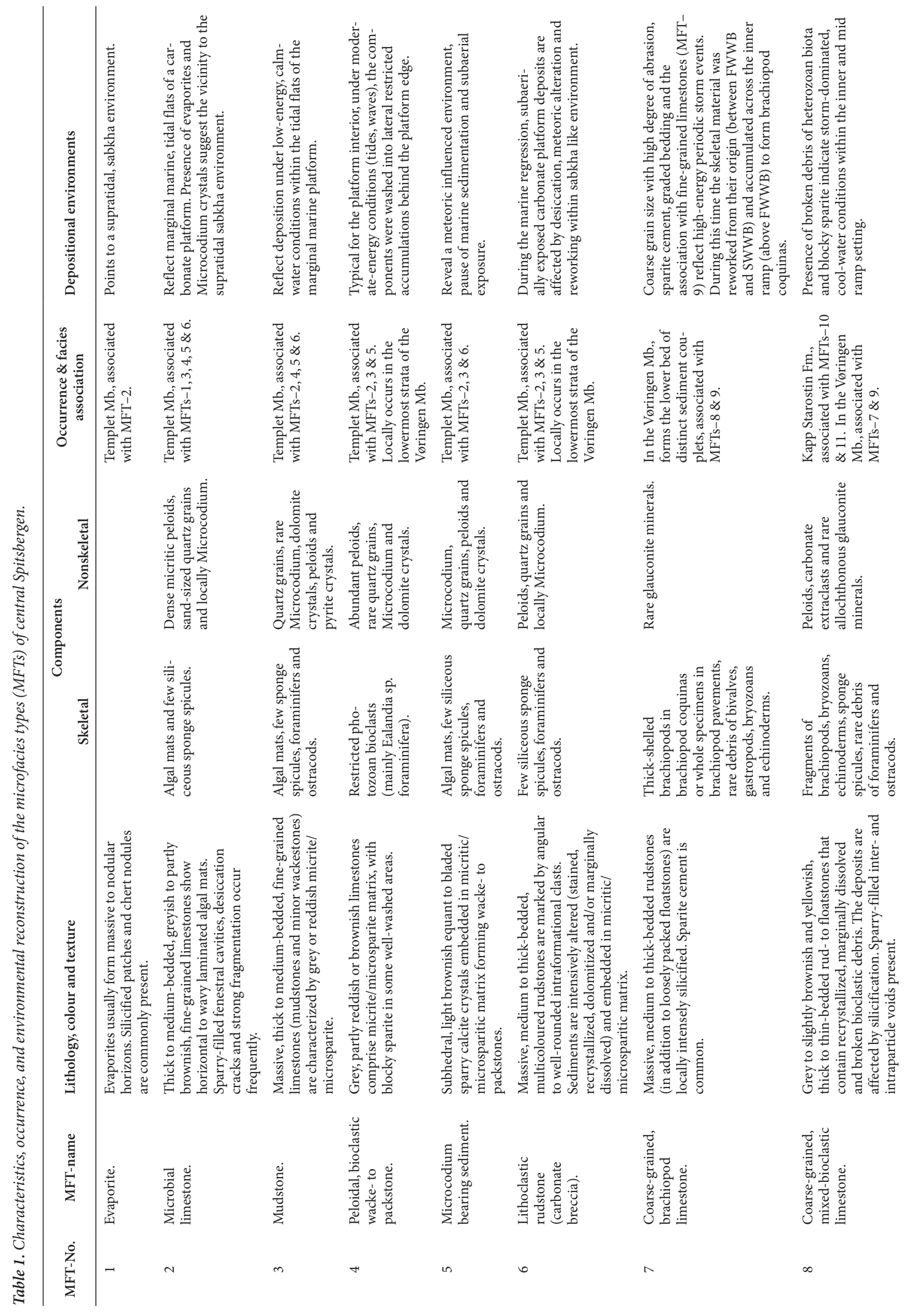




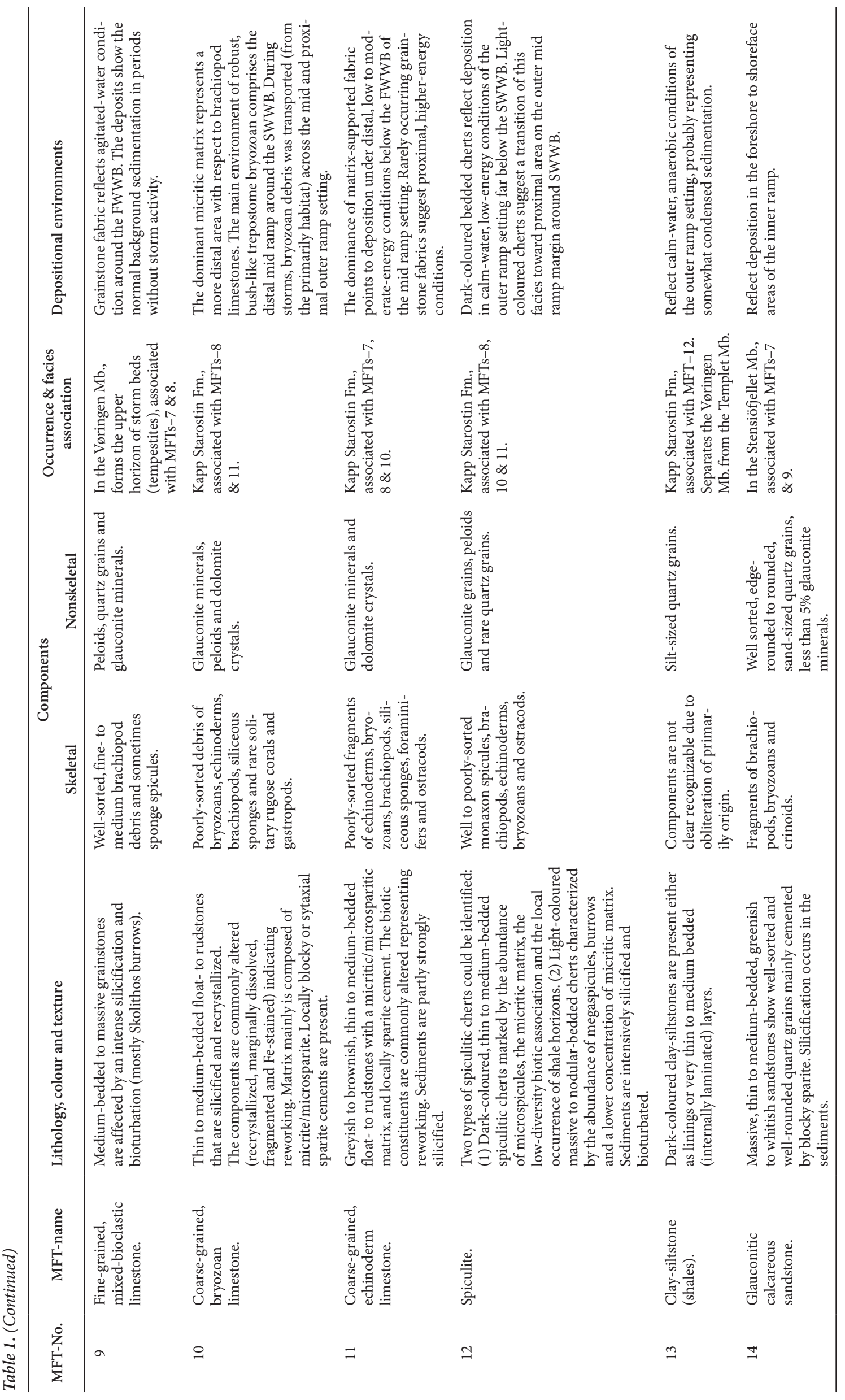


with claystone partings (MFT-13) occurs, marking the overall appearance of the Kapp Starostin Formation. At the top, the Stensiöfjellet Member consists of thick, greenish, glauconitic sandstone beds (MFT-14), whitish massive to nodular-bedded cherts (MFT-12) and minor allochemical limestones (MFT-7).

\section{Idodalen section (ID)}

Section Idodalen (Fig. 1) contains $6 \mathrm{~m}$ of the Templet Member and $91 \mathrm{~m}$ of the Kapp Starostin Formation, including a $7.5 \mathrm{~m}$-thick Vøringen Member at the base.

The Templet and Vøringen members in this section are lithologically similar to those present in section Kapp Fleur de Lys. The strata above the Vøringen Member are also analogous to those encountered in section Kapp Fleur de Lys. However, after $60 \mathrm{~m}$ from the base of the section, the uniform chert series (MFT-12) is interrupted by a distinctive series of coarse-grained, bioclastic (bryozoans, brachiopods, crinoids) limestones (MFTs-10 $\& 11)$. Above this sequence, the section continues with 25 $\mathrm{m}$ of dark to ochre-coloured, massive to nodular-bedded cherts (MFT-12).

\section{Tålmodryggen section (TR)}

Section Tålmodryggen (Fig. 1) comprises $20 \mathrm{~m}$ of the Templet Member and $98 \mathrm{~m}$ of the Kapp Starostin strata, including a $7.5 \mathrm{~m}$-thick Vøringen Member at the base.

The Templet Member is characterised by intercalations of white evaporites (MFT-1) and algal limestones (MFT2) that are overlain by lithoclastic rudstone (breccia) layers (MFT-6). The Vøringen Member is marked by transgressive horizons of grey to light brown, carbonate breccia (MFT-6) followed by thin- to medium-bedded, multicoloured claystone horizons (MFT-13). Higher up in the succession, sediment couplets occur consisting of an alternation of brachiopod limestones and finegrained, bioclastic limestones (MFTs-7 \& 9) with abundant Skolithos burrows. Unlike in the sections at Idodalen and Kapp Fleur de Lys, section Tålmodryggen contains lenses and horizons of coarse lithoclasts (pebbles). Sandy horizons crop out in the topmost massive chert units of the Vøringen Member.

The sediments of the Kapp Starostin Formation continue with a monotonous series of dark to ochre-coloured cherts (MFT-12) with dark claystone linings and horizons (MFT-13). At $60 \mathrm{~m}$ from the base of the section, a $5 \mathrm{~m}$-thick interval of silicified, bioclastic limestones containing fragments of bryozoans, brachiopods, corals and siliceous sponges (MFT-10) is present which is followed by shale horizons. At $86 \mathrm{~m}$ from the base of the section, a second series of bioclastic carbonates (MFTs$10 \& 11 ; 14 \mathrm{~m})$ is present. The uppermost part of this section is marked by units of white, massive chert (MFT$12 ; 20 \mathrm{~m})$.

\section{Discussion}

\section{Depositional model}

\section{Depositional model of the Templet Member}

The various microfacies of the Templet Member (MFTs$2,3 \& 4$ ) show an abundance of peloids and a poorly diversified photozoan biotic association (predominantly algae), which reflects warm and hypersaline, restricted shallow-water conditions (Fig. 3) (Groen, 2010). The carbonate sediments of the Templet Member, which have mud-supported textures, most likely accumulated in a marginal marine, peritidal setting of a tropical carbonate platform, above the FWWB (Blomeier et al., 2011). The presence of sabkha setting evaporites (MFT-1) in the Templet Member is indicative of an arid to semiarid climate. The occurrence of quartz grains in this member confirms its proximity to the hinterland.

During a marine regression in Sakmarian-Artinskian time, limestone strata of the Templet Member emerged and were subjected to erosion and karstification. The lithoclastic rudstone (MFT-6) is interpreted as the end product of this process.

\section{Depositional model of the Tempelfiorden Group}

The Kapp Starostin Formation was deposited in an intracratonic basin characterised by gentle uniform depositional slopes, which is the most common basin type for the development of a ramp-type system (Ehrenberg et al., 2001). It consists of chert horizons in combination with cold-water carbonate sediments marked by gravel-sized heterozoan biota and the presence of glauconite grains. Ooids and aggregate grains are absent. These sediments were deposited on a ramp-type morphology. The depositional anatomy is constant and laterally extensive, as is evident from limited lateral microfacies variations and the similarities of sedimentation patterns amongst the studied sections. The ramp system displays various sub-environments from the inner (around foreshore to fair-weather wave base, FWWB) to mid (between FWWB and stormweather wave base, SWWB) to the outer ramp (below SWWB) that are characterised by particular microfacies types (Fig. 4).

\section{Depositional model of the Vøringen Member}

Sediments of the Vøringen Member show a different depositional environment than the warm and hypersaline conditions of the Templet Member. In the transgressive deposit of the Vøringen Member, the photozoan association switched to a heterozoan assemblage, represented by crinoids, brachiopods and bryozoans, as well as siliceous sponge spicules (Bryonoderm facies; Hüneke et al., 2001). Brachiopods are the main constituent and accumulated on shell banks (coquinas) within an inner ramp system (Fig. 4), forming 


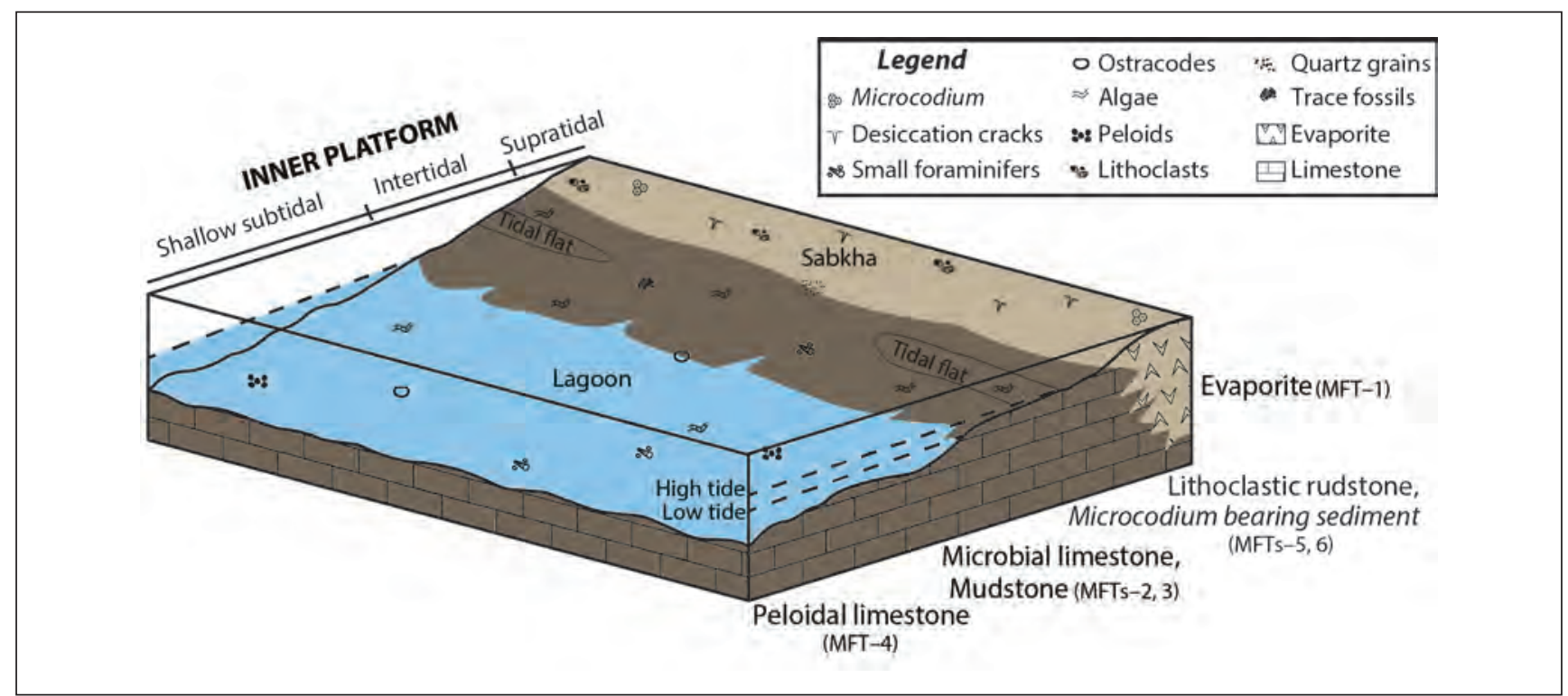

Figure 3. Schematic 3D model of a flat-topped carbonate platform for the Templet Member in central Spitsbergen, showing distribution of the main microfacies and biota across the platform. Adapted from Blomeier et al. (2011). Symbols show the main components of the sediments.

coarse-grained, brachiopod limestones (MFT-7). The predominance of the sparite-filled primary pore space and the high degree of roundness of the individual grains implies that high-energy conditions predominated during deposition of the inner and mid ramp microfacies (Groen, 2010; Blomeier et al., 2011). This microfacies (MFT-7) occurs associated with coarse-grained, mixedbioclastic limestones (MFT-8) consisting of broken fragments of bryozoans, echinoderms and siliceous sponge spicules, which were transported from the midramp area by strong onshore storm surges (Blomeier et al., 2011, 2013). The fine-grained, mixed-bioclastic limestones (MFT-9) form the upper part of the Vøringen Member and reflect sedimentation under normal conditions in an agitated shoreface area (Groen, 2010; Blomeier et al., 2011).

The coarse grain size of the skeletal debris, the finingupward trend, and occasional erosive surfaces provide evidence for the deposition of proximal tempestites in the inner-ramp setting (Flügel, 2004). Hence, the ramp system has been subjected to the impact of storms repeatedly. In the fine-grained, mixed-bioclastic limestones (MFT-9), extensive bioturbation (mainly by Skolithos and Zoophycos trace fossils) and occasional glauconite minerals indicate low sedimentation rates and suggest breaks in the storm activity. Reid et al. (2007) and Blomeier et al. (2013) interpreted the occurrence of trace fossils in the upper part of storm deposits as the increased activity of opportunistic sediment feeders in the aftermath of a storm.

\section{Depositional model of the Kapp Starostin strata}

Bryozoans and echinoderms are the minor carbonateproducing elements in the mid-ramp setting (Blomeier et al., 2011, 2013). Their carbonate production rates are significantly lower than the photozoan biota that dominate the tropical carbonate deposits of the Gipshuken Formation. This is compatible with reduced accumulation rates of cold-water carbonate ramps in comparison with high rates in tropical environments (James, 1997; Blomeier et al., 2013). The correlation of outcrop sections on Spitsbergen and results of seismic mapping on the Finnmark Platform show that limestone beds that are rich in large, little-abraded, bryozoan debris, crinoids and sponges (MFT-10) formed as isolated banks. They gradually change into spiculite and shale-dominated deposits (Malkowski \& Hoffman, 1979; Fredriksen, 1988; Ehrenberg et al., 2001). Autochthonous bryozoans, echinoderms and siliceous sponges may even contribute to the formation of local build-ups in areas of favourable topography or nutrient supply around the SWWB (Ehrenberg et al., 1998).

In the study area, allochthonous bryozoan and echinoderm limestones (MFTs-10 \& 11) within the Kapp Starostin strata are characterised by thinner, mud-rich beds that show minor grading. Toward deeper depositional environments these deposits are interbedded with shale and spiculitic cherts representing distal tempestites that probably formed during a sealevel fall (Fig. 4). The phenomenon of storm activities perturbing the mid-ramp ocean floor is in agreement with a mid-latitude location (Morton, 1981). 


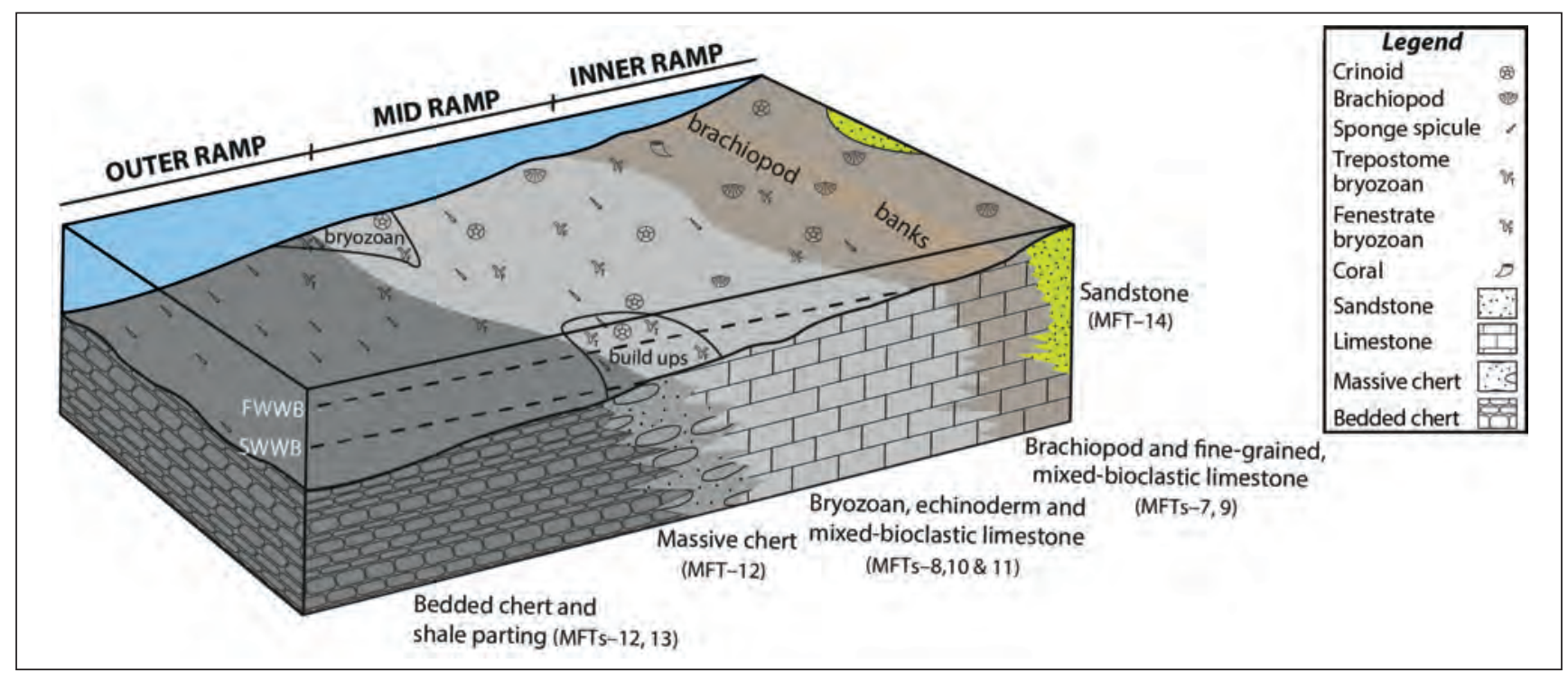

Figure 4. Schematic 3D carbonate ramp model for the Kapp Starostin Formation in central Spitsbergen, showing distribution of the main microfacies and biota across the inner, mid and outer ramp settings. Adapted from Blomeier et al. (2013). Symbols show the main components of the sediments.

The thin- to medium-bedded, dark-coloured spiculitic cherts (MFT-12) with shale partings (MFT-13), which constitute the main lithology of the Kapp Starostin Formation, formed within the cold-water, low-energy conditions of the outer ramp (Fig. 4). The presence of glauconite suggests a low sedimentation rate, most likely below the SWWB, and the presence of burrows is indicative of aerobic conditions (Beauchamp \& Baud, 2002). The occurrence of shale horizons and a lime-mud matrix might have led to the dark colour of the bedded cherts (Gates et al., 2004).

In the investigated area, the light-coloured, massive cherts (MFT-12) are succeeded by dark-coloured, bedded cherts suggesting that they have closely related depositional histories. The massive cherts contain larger spicules, a lower matrix content and more recognisable bioclasts of brachiopods, ostracods and bryozoans, which are evidence of a more energetic environment with respect to the bedded cherts (Ehrenberg et al., 2001) This unit was likely deposited on the outer mid-ramp margin around SWWB. The light-coloured nature, and the occurrence of extensive bioturbation and various biota in these deposits point to oxygenated depositional conditions.

The presence of glauconite and silica deposits specifically in the mid- to outer-ramp microfacies is related to upwelling currents, which could have brought substantial amounts of nutrients onto the ramp (Beauchamp \& Baud, 2002; Gates et al., 2004). Seasonal thawing of northern seaice sheets led to the production of dense, cold water in the deep northern Panthalassan Ocean, displacing nutrients and silica-rich water to the western and northern shelfal areas of Pangea via upwelling. This process created an environment favouring siliceous biogenic productivity (Beauchamp \& Baud, 2002). Additionally, the closure of the Uralian seaway during the Kungurian caused the cutoff of the supply of warm waters of the Tethys (Blomeier et al., 2011). Changes in oceanic circulation patterns accompanied by local palaeogeographical changes during the northward movement of Pangea hence resulted in the decrease of the water temperature from warm to temperate and cold marine conditions along the western and northern margin of Pangea (Beauchamp, 1994; Stemmerik \& Worsley, 1995; Reid et al., 2007; Beauchamp \& Grasby, 2012).

\section{Depositional model of the Stensiöfjellet Member}

The microfacies types of the Stensiöfjellet Member grade from massive spiculitic cherts (MFT-12) at the base to distinct, green, glauconitic sandstones (MFT-14) with sporadic brachiopod limestone horizons (MFT-7) (Fig. 4). The well-sorted and well-rounded quartz grains indicate that the sediments have been deposited in a high-energy near-shore area. Glauconite also has been found within this member, which according to Blomeier et al. (2013) was formed by post-depositional, early diagenetic processes that occurred when deeper, quietwater conditions of the overlying Sassendalen Group dominated the region. During latest Permian time, rapid global warming and complete melting of the northern sea ice entirely rearranged the palaeo-oceanographic setting which led to the extinction of several families of silicasecreting organisms (Wignall et al., 1998; Beauchamp \& Baud, 2002). 


\section{Microfacies arrangement and cycle stacking pattern}

\section{Third-order cyclicity}

Based on outcrop observations and the microfacies analysis, five parasequences (S0, S1, S2, S3 \& S4) as components of individual systems tracts were recognised within all stratigraphic sections. A parasequence is defined as a package of beds that is deposited as a result of third-order sea-level fluctuations, probably caused by glacio-eustatic processes, with a magnitude of several tens of metres and a periodicity of 1-10 Myr (Nichols, 1999). Each parasequence reflects sedimentation from the deepest to the shallowest marine environments at the top. Marine flooding surfaces mark the boundary between parasequences (PSB) and are characterised by an abrupt increase in relative sea level and a sudden shift from shallowest to deepest microfacies (Nichols, 1999). Therefore, the parasequence boundaries (PSB) are defined at the top of the shallowest marine unit.

Fourth- and fifth-order cycles (periodicity of 10-500 Kyr), together with high-energy storms, locally affected the chert-dominated parasequences and subdivided them into a number of temporally restricted, shallowingupward cycles (Fig. 5). Waves and currents set up by storms transported sediments such as single bioclastic limestones or sand grains from the inner or mid ramp towards the chert-rich outer ramp setting. These storm beds (tempestites) have limited extension and are common in the shallowing-upward sequences.

\section{Parasequence SO: Templet Member}

In S0, the microbial limestones and mudstones (MFTs-2 \& 3) grade into lithoclastic rudstones and Microcodium-bearing sediments (MFTs-5 \& 6) to form a shallowing and coarsening-upward pattern (Fig. 5). The occurrence of Microcodium and intraclasts is indicative of the prevalence of terrestrial conditions with subaerial exposure. The top of this regressive cycle represents a hiatus and is defined as the sequence boundary (SB) separating S0 from S1. The thickness of S0 varies between $\sim 2 \mathrm{~m}$ in section Kapp Fleur de Lys to $\sim 20 \mathrm{~m}$ in section Tålmodryggen.

\section{Parasequence S1: Vøringen Member}

Above the sequence boundary (SB), a claystone horizon (MFT-13) forms the base of S1 in section Idodalen. We assume it is also present in section Kapp Fleur de Lys, but it was not observed there due to limited exposure. The claystone represents a substantial relative rise in sea level and reflects a period with sediment-starved conditions in a deep-marine setting.

In section Tålmodryggen, the presence of extraclasts (MFT-6) at the base of S1 indicates that erosion took place as a result of high wave energy in the shallow-water environment. We suggest that this occurred during the onset of a transgression, flooding the land surface and reworking earlier deposits. Therefore, in this section, the Templet Member (S0) is separated from the overlying Vøringen Member (S1) by a disconformity (SB). At the other localities, this surface (SB) is marked by subaerial exposure and a paraconformity related to non-deposition instead of the erosional surface.

The shallowing-upward trend in $\mathrm{S} 1$ is characterised by the successive deposition of coarse-grained, silicified, bioclastic limestones (MFTs-7, 8 \& 9). The occurrence of fine-grained, bioclastic limestones at the top of this succession records a renewed deepening of the depositional setting at the transition towards the overlying sequence. In all measured sections the thickness of $\mathrm{S} 1$ is $\sim 7.5 \mathrm{~m}$.

\section{Parasequence S2}

S2 in the Kapp Starostin Formation records a deepening in a cold-water setting, which is inferred from the occurrence of widespread, bedded cherts with shale partings (MFTs-12 \& 13; Fig. 5). These basal sediments pass over into massive cherts and, to a lesser extent, into heterozoan carbonates (MFTs-10 \& 11) with an outer mid-ramp signature. S2 is the thickest cycle ranging from $71 \mathrm{~m}$ in section Kapp Fleur de Lys to $37 \mathrm{~m}$ in section Tålmodryggen.

\section{Parasequences S3 \& S4}

The third and fourth shoaling-upward parasequences show a similar microfacies arrangement. In S3, the basal deep-water microfacies comprising clay horizons and chert units shift progressively to shallower microfacies, bryozoan and echinoderm limestones (MFT-10 \& 11). The top of S4 is only exposed in section Kapp Fleur de Lys (Stensiöfjellet Member) in which cherts are overlain by brachiopod limestones and glauconitic sandstones (MFTs-7 \& 14). The succession in S4 reveals a decrease in sea level and an overall shallowing of the depositional area from an outer- to an inner-ramp setting.

The thickness of S3 varies between $12 \mathrm{~m}$ in section Idodalen and $34 \mathrm{~m}$ in section Tålmodryggen. S4 displays thickness variations ranging from $20 \mathrm{~m}$ (section Tålmodryggen) to 30 m (section Kapp Fleur de Lys).

\section{Second-order cyclicity}

The overall Permian succession represents a secondorder cycle, with a duration exceeding 16 Myr. It can be subdivided into several systems tracts (Fig. 5). An overall shoaling trend approaching the PermoTriassic boundary is reflected by systematic changes in cycle thickness (thinning up), and by changes in the proportion of outer-ramp and inner-ramp microfacies (the latter increases) of the individual parasequences when moving upwards in the succession. This finding is 

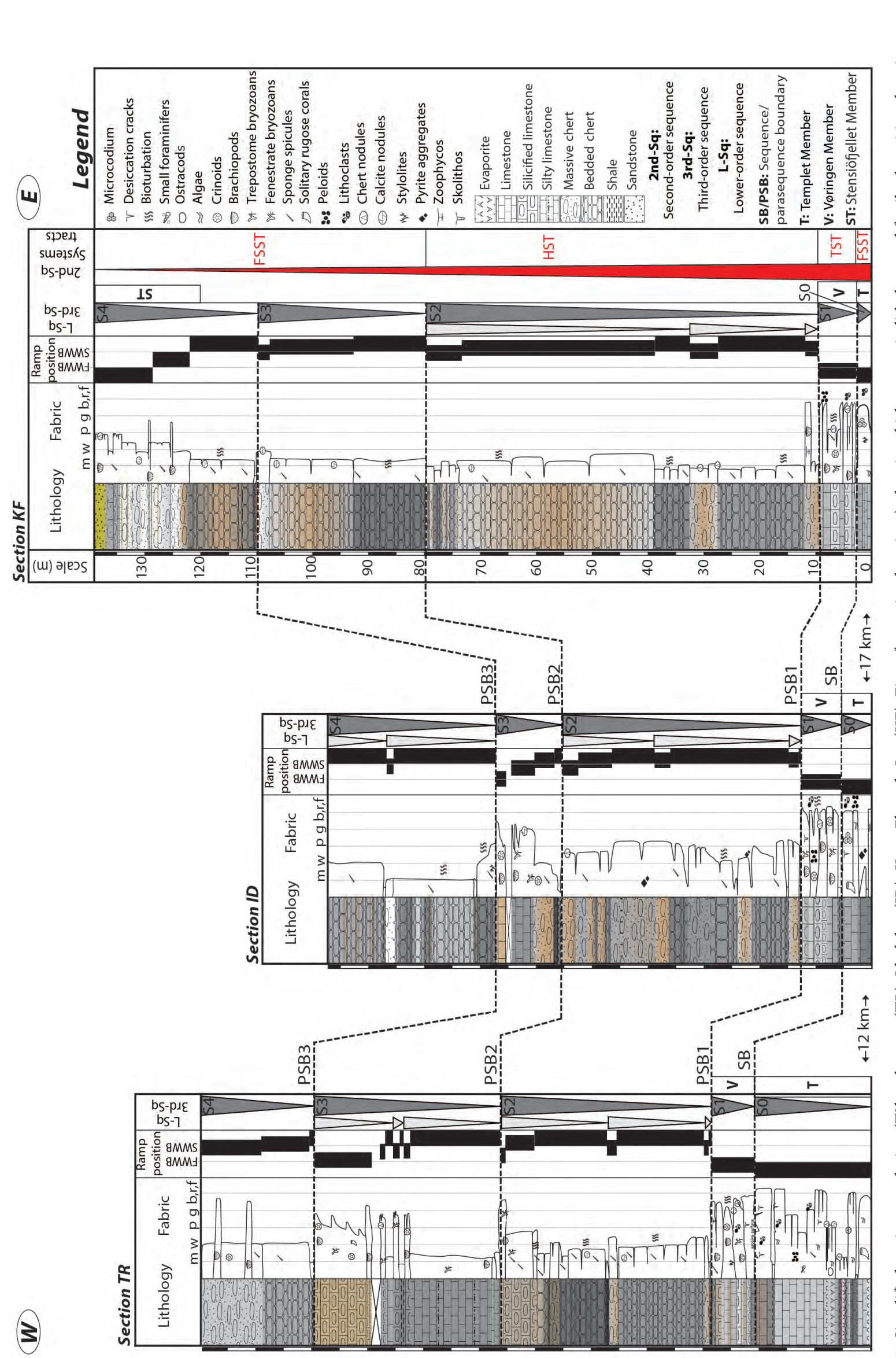

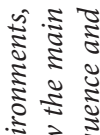

है ㅎํ

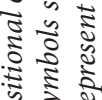

के क

जิ

능

काँ

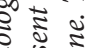

ㄴำ

है

की

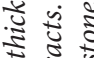

bo 5

है है

ईิ

हี ซั

ट

$\approx .5$

है क्षे

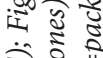

这 8

군

옹

I

एक

है है

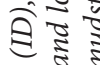

ฐ๊

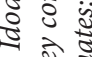

दि के०

है है

离

을

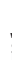

을

ह है

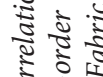

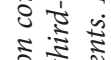

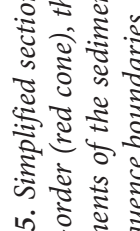

Wh 
in line with the global sea-level curve compiled by Haq \& Schutter (2008) which displays a general shallowing trend during the Late Permian.

\section{Falling stage systems tract (FSST)}

The first falling stage systems tract comprises the strata of S0 with the upper subaerial sequence boundary (SB) marking the lowest position in relative sea level in the study area. The shoaling-upward trend reflects a reduction in the creation of accommodation space relative to sediment supply, resulting from a forced regression or a sea-level fall (Nichols, 1999).

\section{Transgressive systems tract (TST)}

S1 represents the stratigraphic succession between the lower sequence boundary (SB) and the maximum flooding surface (shale) and is interpreted as a component of the transgressive systems tract (Fig. 5). The coarse-grained, bioclastic limestones show an upward deepening into fine-grained, bioclastic limestones indicative of a retrogradational pattern. The depositional trends indicate that the creation of accommodation space during transgressions out-paced sediment supply.

\section{Highstand systems tract (HST)}

The maximum flooding surface (black shale) separates carbonate-dominated, inner-ramp deposits of the Vøringen Member (S1) from the deep-water spiculitic cherts of the Kapp Starostin Formation (S2). It reflects the termination of shallow-marine sedimentation and sediment starvation on the outer part of the ramp system. Deposition beyond the maximum flooding surface, S2, is considered to be part of the highstand systems tract. During the long-lived, highstand systems tract, the rate of sea-level rise slowed down, and cold, silica-rich, deeper waters were brought in via upwelling and created an environment favouring extensive biogenic silica production. The sedimentary succession shows an aggradational to slightly progradational pattern which is reflected by a shift from bedded to massive cherts and, to a lesser extent, to bioclastic limestones.

\section{Falling stage systems tract (FSST)}

The second falling stage systems tract is made up of S3 and S4 that record a higher portion of shallow-water microfacies (carbonates and sandstones) with respect to the parasequence below. Hence, these parasequences show a trend of becoming shallower up through the succession. The deposits indicate that the shoreline has moved seawards at the transition to the sediments of the Triassic Sassendalen Group when, during the latest Permian, the climatic conditions changed dramatically leading to a drop in sea level (Haq \& Schutter, 2008).

\section{Correlation in central Spitsbergen}

The Spitsbergen cross-section, correlating three sections, is oriented west-east and covers the proximal and distal part of the Permian ramp system (Fig. 5). A proximal setting is situated in the west of the cross-section, in section Tålmodryggen. This setting is marked by (i) the presence of shallower microfacies such as the sabkhaevaporites that occur in the Templet Member (S0), (ii) the extraclasts and sandy deposits in the Vøringen Member (S1), and (iii) the higher portion of limestones in the Kapp Starostin Formation (S2, S3 \& S4). Section Tålmodryggen is located on the Nordfjorden High, which was a persistent positive feature (horst block) during the Carboniferous-Permian. This also explains why the sedimentary successions record shallower-water conditions in comparison with other sections (Steel \& Worsley, 1984; Ehrenberg et al., 2001). During the deposition of the Kapp Starostin strata (S2, S3 \& S4), the main depocentre was located near section Kapp Fleur de Lys that contains a thick succession of deep-water microfacies such as bedded cherts (MFT-12).

In all studied sections in central Spitsbergen, the dominance of bedded cherts in the Kapp Starostin Formation (S2, S3 \& S4) suggests that the environment was one of low hydrodynamic energy. However, the presence of wave-generated sedimentary structures indicates periodic disturbances by storms.

\section{Correlation with other sections on Svalbard}

The analysed outcrop sections are compared with sections (i) described by Ehrenberg et al. (2001), who worked in southwestern (at Akseløya; section AK) and central Spitsbergen (at Dickson Land, section D-L), and (ii) those of Blomeier et al. (2013) who documented four sections in northeast Svalbard (sections E, H, S \& Z) (Fig. 6). On Spitsbergen and northeastern Svalbard, Ehrenberg et al. (2001) and Blomeier et al. (2013) reported that the successions of the Kapp Starostin Formation were deposited as a result of third-order sea-level fluctuations. They stated that the overall stacking pattern is characterised by long-term regression, which can be interpreted as a second-order cycle. These findings are in line with the results of the present study.

\section{SO}

In central Spitsbergen, the Templet Member (S0) comprises photozoan elements and some evaporites indicating arid and tropical conditions. At the same time, a minor part of the sedimentary record in northeast Svalbard is marked by heterozoan elements. The majority 
(u)
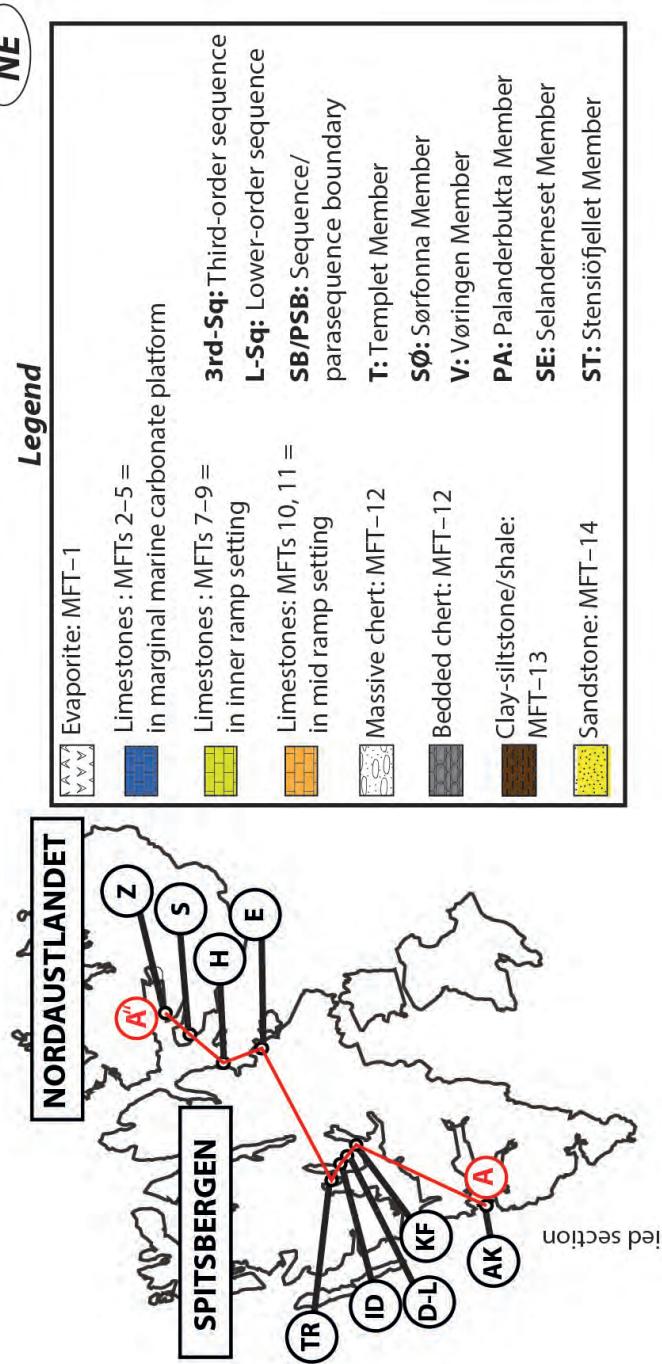

uopas papms a
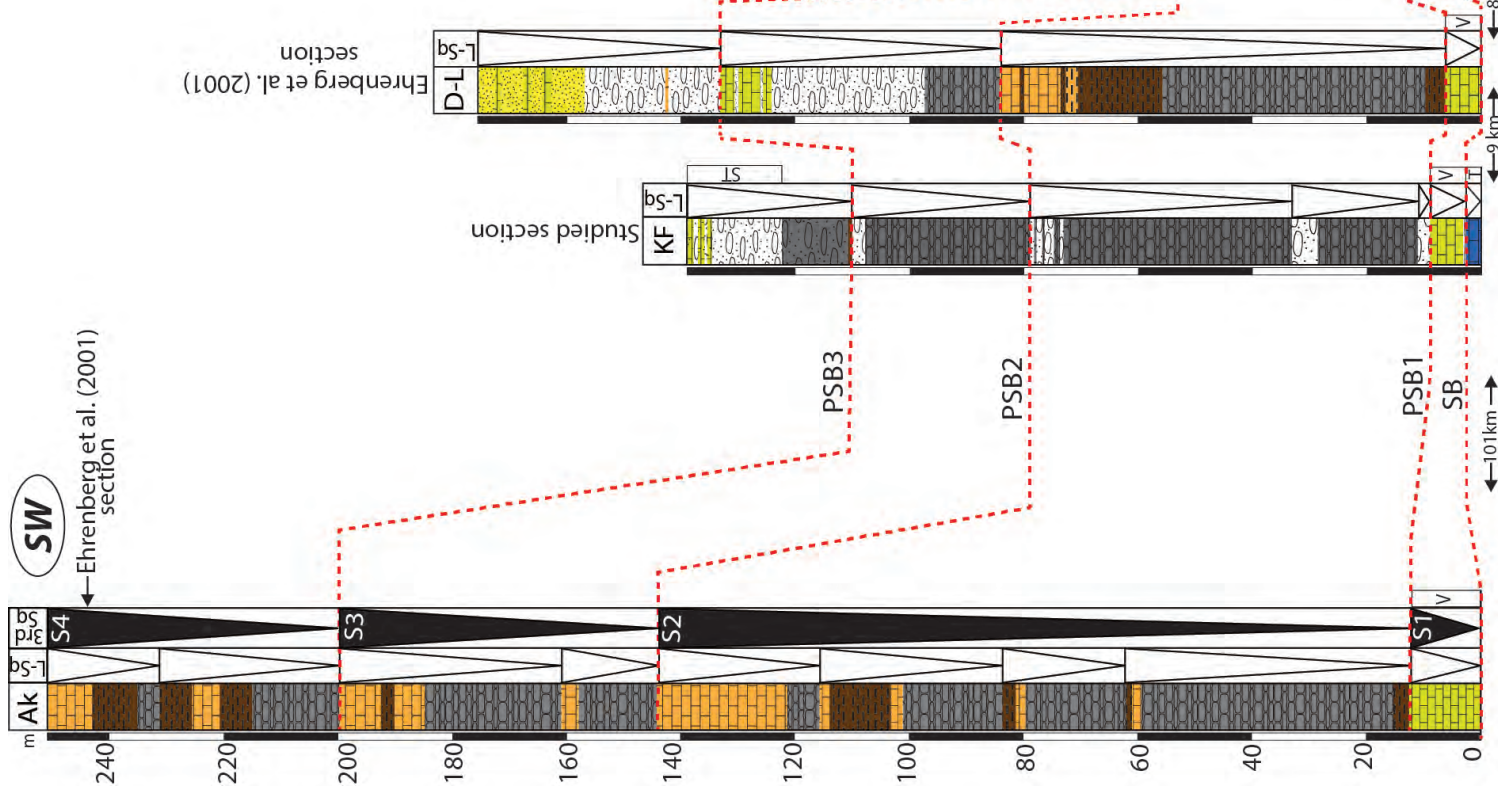

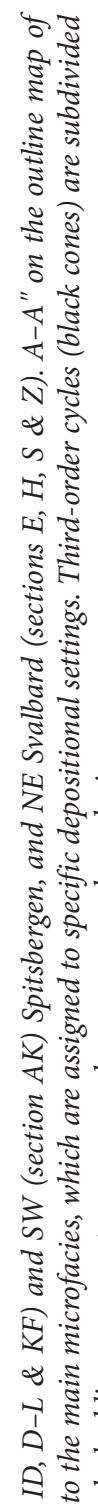

है है

के के

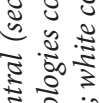

焉焉

वे.

क्षे के

ㅇํㅇำ

원

₹

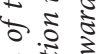

ป

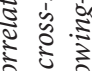

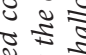

5

离

0.0

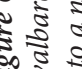


of the carbonate deposits, however, are characterised by a photozoan biotic assemblage. Such a mix of biota is also known from tropical environments of Mauritania, Panama and the Galapagos Islands (Michel et al., 2011; Reijmer et al., 2012; Reymond et al., 2016). The higher siliciclastic input observed in northeast Svalbard results from the uplift of a terrestrial source area as well as an increased runoff rich in dissolved silica, due to more humid subtropical environments (Blomeier et al., 2011).

\section{S1}

The transgression that flooded the ramp during the Artinskian covered the entire Svalbard region (SW to NE). The Vøringen Member (S1) that is present in all sections shows that the whole area was covered by carbonates with a predominance of heterozoan biotic assemblages (Fig. 6). Blomeier et al. (2011, 2013) stated that at the base of the Vøringen Member in northeast Svalbard, in situ bryozoan build-ups occurred on the hardgrounds and the condensed surface substrate. The bryozoans do not occur in the Vøringen Member in central and southwestern Spitsbergen. Instead, brachiopod fragments are present in the basal beds. The deeper environment of northeast Svalbard during this time interval (S1) can be explained by a local higher subsidence rate, which possibly linked to the reactivation of the Carboniferous Lomfjorden trough, a smaller graben east of the Lomfjorden-Agardhbukta Fault Zone (Blomeier et al., 2009).

\section{S2, S3 \& S4}

The deepening trend recorded in the Kapp Starostin succession is characterised by spiculitic cherts, which occur in the whole area (S2, S3 \& S4) (Fig. 6).

In northeast Svalbard and on the Finnmark Platform (Norwegian Barents Sea), occurrences of whole sponges have been reported from the outer-ramp to the outermid ramp boundary (Ehrenberg et al., 2001; Blomeier et al., 2013). In northeast Svalbard, the presence of massive cherts, as the main lithology, mixed with shallow-water sandstones and limestones strongly suggests a shoreward transport of spiculitic sediment by wave action and periodic storm events.

In southwestern and central Spitsbergen, dark-coloured, bedded cherts are the dominant microfacies (S2, S3 \& S4), resulting in low accumulation rates in the distal and deeper ramp zones. Shallow-water limestone (brachiopod-rich) intervals and sandstones in northeast Svalbard correlate with deep-water limestones (bryozoan and echinoderm-rich) or massive cherts in southwestern and central Spitsbergen. However, the presence of finegrained, clastic sediments in the southwest could be related to erosion of the Sørkapp-Hornsund High, which remained exposed until the end of the Permian (Dallmann et al., 1999).

The sequence-stratigraphic model (Fig. 6) shows that the Templet (S0) and Vøringen (S1) members reflect deep-water sedimentation in northeast Svalbard. During the deposition of the Kapp Starostin Formation (S2, S3 \& S4), the main sediment depocentre was located in the southwest of Spitsbergen (at Akseløya) which is suggested by the thicker parasequences and the higher proportion of deeper microfacies (e.g., bedded cherts). At the same time, NE Svalbard was located in the most proximal setting, as shown by the thinner sequence and shallower microfacies, e.g., more sandstones and bioclastic limestones. The microfacies distribution patterns show an inclination of the ramp towards the southwest (Fig. 6). The Permian is characterised by a period of tectonic quiescence on Svalbard (Steel \& Worsley, 1984; Dallmann et al., 1999). The local differences in accommodation space and facies may be linked to the older, pre-existing, structural elements, inherited from the reactivation of the main tectonic lineaments throughout the Carboniferous (Ehrenberg et al., 2001; Blomeier et al., 2013).

From northeast to southwest Svalbard, some of the smaller-scale, lower-order cycles within the individual parasequences become amalgamated (Fig. 6). The seaward pinch-out of shallower intervals including single limestone beds and sandstones or the temporary change from bedded into massive cherts, resulted in a decrease in the number of shallowing-upward cycles. The lateral facies distribution indicates an increase in hydrodynamic energy with shallowing water depths across the more subdued relief ramp environment.

\section{Comparison with other time- and facies- equivalent systems in Arctic and sub- Arctic parts of the Northern Hemisphere}

\section{Templet Member}

The cold-water carbonates of the lower part of unit L-8 in the Finnmark Platform and heterozoan carbonates with minor photozoan elements of the Great Bear Cape Formation in the Sverdrup Basin (Arctic Canada), are known as offshore equivalents of the Templet Member on Spitsbergen (Larssen et al., 2002; Bensing et al., 2008). The variations in the distribution of the biota (heterozoan and photozoan) indicate that subtropical and cooler climatic conditions were dominant in the deeper depositional areas of the Pangaean shelf. This depositional setting is characterised by the absence of light and the presence of cold, nutrient-rich water related to upwelling leading to the shutdown of the photozoan carbonate producers. In contrast, warm and tropical climatic conditions, represented by the photozoan 
association, prevailed over structural highs such as the Fafner succession on the Loppa High (SW Barents Sea; Ahlborn et al., 2014) and along the margins of the Franklinian shelf like Spitsbergen.

The Late Sakmarian-Early Artinskian uplift along the shelf margin and over structural highs led to subaerial exposure and karstification at the top of the Fafner and Gipshuken formations indicating a very proximal setting during the sea-level fall (Groen, 2010; Ahlborn et al., 2014). Contemporaneously, a period of non-deposition and sea-floor exposure is indicated by the occurrence of silty shale with pyrite cementation and a glauconiteenriched surface within the Finnmark Platform (Ehrenberg et al., 2001; Stemmerik \& Worsley, 2005). Towards the Nordkapp Basin, sediments consist mainly of cool-water carbonates and bryozoan build-ups.

\section{Vøringen and Kapp Starostin strata}

During the Mid/Late Artinskian, a major transgression flooded the shelf margins and structural highs resulting in the deposition of extensive carbonates along the northern margin of Pangea (Steel \& Worsley, 1984; Blomeier et al., 2011). The upper parts of unit L-8 (Isbjørn Formation) of the Finnmark Platform and the Great Bear Cape Formation within the Sverdrup Basin are considered to correlate with the Vøringen Member on Spitsbergen (Stemmerik \& Worsley, 2005). They are characterised by crinoid, bryozoan and brachiopodrich limestones deposited in inner-shelf environments. However, in the Sverdrup Basin, elements of the subtropical biota such as fusulinids and colonial corals are present in the shallowest near-shore microfacies (Larssen et al., 2002; Reid et al., 2007). In this locality, evidence of subaerial exposure at the top of the Great Bear Cape Formation and succeeding deltaic deposits of the Sabine Bay Formation might relate to compressional tectonic events during the Kungurian-Melvillian. This tectonic activity caused uplift of the Sverdrup basin margins (Reid et al., 2007). During the remainder of Permian time, the Sverdrup Basin records the onset of passive subsidence, except for a localised uplift of the Tanquary High in the northeast (Reid et al., 2007; Bensing et al., 2008).

On the Finnmark Platform, an unconformity or subaerial exposure surface is also recorded on the topmost part of unit L-8 just below the overlying unit L-9 (Stemmerik \& Worsley, 2005; Rafaelsen et al., 2008). This uplift was linked to the Kungurian tectonic event in the western Barents Sea resulting from the rejuvenation of older lineaments (Stemmerik \& Worsley, 2005; Ahlborn et al., 2014). However, on Svalbard, the transition between the Vøringen Member and the overlying Kapp Starostin Formation is conformable.

A deepening of the basin and cold-water climatic conditions during deposition of the spiculitic cherts of the Kapp Starostin Formation have also been recorded in the Lindstrom Formation situated at the margin of Sverdrup Basin and in unit L-9 in the Finnmark Platform (Gates et al., 2004). In the Lindstrom Formation, lightcoloured, massive cherts are marked by large spicules and cold-water carbonate biofragments, which show hummocky cross-stratification. These sediments were deposited in an outer- to inner-ramp setting (Gates et al., 2004). An overall increase in spicule size with decreasing bathymetry suggests shoreward transport of spicules during periodic storm events. The presence of concavedown brachiopods along bedding planes suggests hydrodynamic sorting and sediment transport (Gates et al., 2004). Accordingly, Late Permian spiculites in the Sverdrup Basin accumulated in shallower depths than those in central Spitsbergen, which can be interpreted either as a general stormier setting or might be due to a low-relief ramp-type morphology with restricted biological diversity (Gates et al., 2004). Similarly, on the Finnmark Platform, larger spicules, a reduced matrix, and the presence of vuggy fractures in light-coloured spiculites (upper cycle of unit L-9) reflect a higherenergy environment than those recorded in Spitsbergen (Ehrenberg et al., 2001; Seidler et al., 2004; Stemmerik \& Worsley, 2005). A secondary porosity present might have developed during the break at the Permian-Triassic transition as a result of rifting events in the NorwegianGreenland Sea area (Ehrenberg et al., 2001; Seidler et al., 2004; Stemmerik \& Worsley, 2005).

\section{Conclusions}

The Templet Member and the Kapp Starostin Formation on Spitsbergen accumulated during a time of prolonged sea-level fall (second-order) and oceanic cooling. The sedimentary successions can be subdivided into a series of systems tracts and third-order sea-level cycles (five parasequences):

S0 (Templet Member): At the marginal marine environment, algal limestones and mudstones grade into lithoclastic rudstones and Microcodium-bearing sediments suggesting periods of subaerial exposure. The top of this regressive cycle represents a hiatus and is defined as the sequence boundary (SB). This parasequence is a component of the falling stage systems tract.

S1 (Vøringen Member): At an inner to proximal mid-ramp setting, storm-influenced, silicified brachiopod limestones occur showing an upward deepening into fine-grained, heterozoan limestones during transgression. This parasequence represents a transgressive systems tract.

S2, S3 \& S4 (Kapp Starostin Formation): These parasequences are predominantly characterised by 
widespread spiculitic cherts deposited in an outer-ramp setting. These deep-water deposits shift up-section increasingly into bioclastic limestones and sandstones, which represent a highstand systems tract (S2) and falling stage systems tract (S3 \& S4).

The correlation of the sections in central Spitsbergen indicates that the proximal areas of the ramp setting are located in the west. The main sediment depocentre is situated in the region near section Kapp Fleur de Lys in the east and is characterised by a thick succession of deep-water bedded cherts.

The stratigraphic correlation along different locations in Svalbard shows that during the deposition of the Templet and Vøringen members, northeast Svalbard recorded deeper-water microfacies than in central Spitsbergen. This can be explained by high local subsidence rates related to the reactivation of Carboniferous structural elements. During the latest Permian, the main sediment depocentre was located in the southwest of Spitsbergen at Akseløya, which displays thicker parasequences and a higher proportion of bedded cherts than at other locations. These deposits are slightly shallower towards central Spitsbergen, and display a significant shallowing towards northeastern Svalbard.

The correlation of the studied succession from Spitsbergen with other successions along the northern margin of Pangea shows that during Early Artinskian time, warm and tropical climatic conditions prevailed over structural highs, such as the Fafner succession on the Loppa High (SW Barents Sea) and along the margins of the Franklinian shelf, e.g., Spitsbergen. Subtropical and cooler climatic conditions dominated the deeper depositional settings such as the Finnmark Platform (Norwegian Barents Sea) and Sverdrup Basin (Arctic Canada). During the Mid/Late Artinskian, a major transgression resulted in the deposition of extensive cool-water carbonates along the northern margin of Pangea. The remainder of the Permian time interval is dominated by the deposition of deep-water spiculitic cherts within the entire study area.

Acknowledgements. We acknowledge the Vrije Universiteit Amsterdam, Bremen University and the Norwegian Polar Institute for their financial support. We thank MSc. students Mahtab Mozafari and Jan Schneider of the Vrije Universiteit Amsterdam for their contributions; and Bouke Lacet and Wynanda Koot for preparing the thin-sections and plugs at the Vrije Universiteit Amsterdam. We thank the College of Petroleum Engineering \& Geosciences for their support during the final stages of the manuscript. Finally, an anonymous reviewer and NJG editor Trond Slagstad (Geological Survey of Norway) are thanked for their very constructive comments and suggestions that significantly improved the paper. This is CPG - Carbonate Sedimentology Group - contribution no. 4 .

\section{References}

Ahlborn, M., Stemmerik, L. \& Kalstø, T.K. 2014: 3D seismic analysis of karstified interbedded carbonates and evaporites, Lower Permian Gipsdalen Group, Loppa High, southwestern Barents Sea. Marine and Petroleum Geology 56, 16-33. https://doi.org/10.1016/j.marpetgeo.2014.02.015.

Anell, I., Braathen, A. \& Olaussen, S. 2014: Regional constraints of the Sørkapp Basin: A Carboniferous relic or a Cretaceous depression. Marine and Petroleum Geology 54, 123-138. https://doi.org/10.1016/j.marpetgeo.2014.02.023.

Beauchamp, B. 1994: Permian climatic cooling in the Canadian Arctic. In Klein, G.D. (ed.): Pangea: paleoclimate, tectonics and sedimentation during accretion, zenith and break-up of a supercontinent, Geological Society of America Special Paper 288, pp. 229-246. https://doi.org/10.1130/SPE288-p229.

Beauchamp, B. \& Desrochers, A. 1997: Permian warm- to very coldwater carbonates and cherts in Northwest Pangaea. In James, N.P. \& Clarke, J.A.D. (eds.): Cool-water carbonates, Society for Sedimentary Geology Special Publication 56, Tulsa, Oklahoma, USA, pp. 327-347.

Beauchamp, B. \& Baud, A. 2002: Growth and demise of Permian biogenic chert along northwest Pangea: evidence for endPermian collapse of thermohaline circulation. Palaegeography, Palaeoclimatology, Palaeoecology 184, 37-63. https://doi.org/10.1016/S0031-0182(02)00245-6.

Beauchamp, B. \& Grasby, S. 2012: Permian lysocline shoaling and ocean acidification along NW Pangaea led to carbonate eradication and chert expansion. Palaegeography, Palaeoclimatology, Palaeoecology 350-352, 73-90. https://doi.org/10.1016/j.palaeo.2012.06.014.

Bensing, J.P., James, N.P. \& Beauchamp, B. 2008: Carbonate deposition during a time of mid-latitude ocean cooling: Early Permian subtropical sedimentation in the Sverdrup Basin, Arctic Canada. Journal of Sedimentary Research 78, 2-15. https://doi.org/10.2110/jsr.2008.004.

Blomeier, D., Scheibner, C. \& Forke, H. 2009: Facies arrangement and cyclostratigraphic architecture of a shallow-marine, warm-water carbonate platform: the Late Carboniferous Ny Friesland Platform in eastern Spitsbergen (Pyefjellet Beds, Wordiekammen Formation, Gipsdalen Group). Facies 55, 291-324. https://doi.org/10.1007/s10347-008-0163-3.

Blomeier, D., Dustira, A.M., Forke, H. \& Scheibner, C. 2011: Environmental change in the Early Permian of Spitsbergen: from a warm-water carbonate platform (Gipshuken Formation) to a temperate, mixed siliciclastic-carbonate ramp (Kapp Starostin Formation). Facies 57, 493-523. https://doi.org/10.1007/s10347-010-0243-z.

Blomeier, D., Dustira, A.M., Forke, H. \& Scheibner, C. 2013: Facies analysis and depositional environments of a storm-dominated, temperate to cold, mixed siliceous-carbonate ramp: the Permian Kapp Starostin Formation in NE Svalbard. Norwegian Journal of Geology 93, 75-93.

Buggisch, W., Blomeier, D. \& Joachimski, M.M. 2012: Facies, diagenesis and carbon isotopes of the Early Permian Gipshuken Formation (Svalbard)[Fazies, Kohlenstoffisotopie und diagenetische Erscheinungen der randmarinen Gipshuken Formation im Unterperm von Spitzbergen]. Zeitschrift der Deutschen Gesellschaft für Geowissenschaften 163, 309-321. https://doi.org/10.1127/1860-1804/2012/0163-0309.

Colpaert, A., Pickard, N., Mienert, J., Henriksen, L.B., Rafaelsen, B. \& Andreassen, K. 2007: 3D seismic analysis of an Upper Palaeozoic carbonate succession of the Eastern Finnmark Platform area, Norwegian Barents Sea. Sedimentary Geology 197, 79-98. https://doi.org/10.1016/j.sedgeo.2006.09.001. 
Cutbill, J.L. \& Challinor, A. 1965: Revision of the stratigraphical scheme for the Carboniferous and Permian rocks of Spitsbergen and Bjørnøya. Geological Magazine 102, 418-439. https://doi.org/10.1017/S0016756800053693.

Dallmann, W.K., Gjelberg, J.G., Harland, W.B., Johannessen, E.P., Keilen, H.B., Lønøy, A., Nilsson, I. \& Worsley, D. 1999: The Upper Palaeozoic lithostratigraphy. In Dallmann, W.K. (ed.): Lithostratigraphic lexicon of Svalbard, Norsk Polar Institutt, Tromsø, pp. 25-126.

Dean, W.E.Jr. 1974: Determination of carbonate and organic matter in calcareous sediments and sedimentary rocks by loss on ignition: comparison with other methods. Journal of Sedimentary Petrology $44,242-248$.

Dunham, R.J. 1962: Classification of carbonate rocks according to depositional texture. In Ham, W.E. (ed.): Classification of carbonate rocks, A symposium, American Association of Petroleum Geologists Memoir 1, pp. 108-171.

Dustira, A.M., Wignall, P.B., Joachimski, M., Blomeier, D., HartkopfFroder, C. \& Bond, D. 2013: Gradual onset of anoxia across the Permian-Triassic Boundary in Svalbard, Norway. Palaeogeography, Palaeoclimatology, Palaeoecology 374, 303-313. https://doi.org/10.1016/j.palaeo.2013.02.004.

Earnest, C.M. 1984: Modern thermogravimetry. Analytical Chemistry 56, 1471-1486. https://doi.org/10.1021/ac00277a786.

Ehrenberg, S., Nielsen, E.B., Svånå, T.A. \& Stemmerik, L.A. 1998: Depositional evolution of the Finnmark Carbonate Platform, Barents Sea: results from wells 7128/6-1 and 7128/4-1. Norwegian Journal of Geology 78, 185-224.

Ehrenberg, S., Pickard, N.A.H., Henriksen, L.B., Svånå, T.A., Gutteridge, P. \& Macdonald, D. 2001: A depositional and sequence stratigraphic model for cold-water, spiculitic strata based on the Kapp Starostin Formation (Permian) of Spitsbergen and equivalent deposits from the Barents Sea. American Association of Petroleum Geologists Bulletin 85, 2061-2087.

Flügel, E. 2004: Microfacies of Carbonate Rocks. Springer, Berlin, Germany, 976 pp. https://doi.org/10.1007/978-3-662-08726-8.

Fredriksen, K. 1988: Sedimentologiske og diagenetiske undersøkelser av Kapp Starostin Formasjonen på Akseløya og Mariaholmen, Bellsund, Svalbard. MSc thesis, University of Tromsø, Norway, 162 pp.

Gates, L.M., James, N.P. \& Beauchamp, B. 2004: A glass ramp: shallowwater Permian spiculitic chert sedimentation, Sverdrup basin, Arctic Canada. Sedimentary Geology 168, 125-147. https://doi.org/10.1016/j.sedgeo.2004.03.008.

Golonka, J. 2002: Plate-tectonic maps of the Phanerozoic. In Kiessling, W., Flügel, E. \& Golonka, J. (eds.): Phanerozoic Reef Patterns, Society for Sedimentary Geology Special Publication 72, pp. 21-70.

Groen, R.D. 2010: From a restricted carbonate platform to a temperate, storm-dominated ramp: The onset of the Permian Chert Event in central Spitsbergen. MSc thesis, Vrije Universiteit Amsterdam, The Netherlands, $105 \mathrm{pp}$.

Haq, B. \& Schutter, S. 2008: A chronology of Paleozoic sea-Level changes. Science 322, 64-68.

https://doi.org/10.1126/science.1161648.

Hüneke, H., Joachimski, M., Buggisch, W. \& Lützner, H. 2001: Marine Carbonate Facies in Response to Climate and Nutrient Level: The Upper Carboniferous and Permian of Central Spitsbergen (Svalbard). Facies 45, 93-136.

Jafarian, E., Kleipool, L.M., Scheibner, C., Blomeier, D. \& Reijmer, J.J.G. 2017: Variations in petrophysical properties of Upper Palaeozoic mixed carbonate and noncarbonate deposits, Spitsbergen, Svalbard Archipelago. Journal of Petroleum Geology 40, 59-83. https://doi.org/10.1111/jpg.12664.

Jafarian, E., De Jong, K., Kleipool, L.M., Scheibner, C., Blomeier, D. \& Reijmer, J.J.G. (in press): Synthetic seismic model of a Permian biosiliceous carbonate-carbonate depositional system (Spitsbergen, Svalbard Archipelago). Marine and Petroleum Geology.
James, N.P. 1997: The cool-water carbonate depositional realm. In James, N.P. \& Clarke, J.A.D. (eds.): Cool-Water Carbonates, Society for Sedimentary Geology Special Publication 56, pp. 1-20. https://doi.org/10.2110/pec.97.56.0001.

Johannessen, E.P. \& Steel, R.J. 1992: Mid-Carboniferous extension and rift-infill sequences in the Billefjorden Trough, Svalbard. Norwegian Journal of Geology 72, 35-48.

Larssen, G.B., Elvebakk, G., Henriksen, L.B., Kristensen, S.E., Nilsson, I., Samuelsberg, T.J., Svånå, T.A., Stemmerik, L. \& Worsley, D. 2002: Upper Palaeozoic lithostratigraphy of the Southern Norwegian Barents Sea. Norwegian Petroleum Directorate Bulletin 9, 1-76.

Laya, J.C. \& Tucker, M.E. 2012: Facies analysis and depositional environments of Permian carbonates of the Venezuelan Andes: Palaeogeographic implications for Northern Gondwana. Palaeogeography, Palaeoclimatology, Palaeoecology 331, 1-26. https://doi.org/10.1016/j.palaeo.2012.02.011.

Malkowski, K. \& Hoffman, A. 1979: Semi-quantitative facies model for the Kapp Starostin Formation (Permian), Spitsbergen. Acta Palaeontologica Polonica 24, 217-230.

Mangerud, G. \& Konieczny, R.M. 1993: Palynology of the Permian succession of Spitsbergen, Svalbard. Polar Research 12, 65-93. https://doi.org/10.3402/polar.v12i1.6704.

Michel, J., Vicens, G.M. \& Westphal, H. 2011: Modern heterozoan carbonates from a eutrophic tropical shelf (Mauritania). Journal of Sedimentary Research 81, 641-655. https://doi.org/10.2110/jsr.2011.53.

Morton, R.A. 1981: Formation of storm deposits by wind-forced currents in the Gulf of Mexico and the North Sea. In Nio, S.D., Shuttenhelm, R.T.E. \& Van Weering, T.J. (eds.): Holocene Marine Sedimentation in the North Sea Basin, International Association of Sedimentologist Special Publication 5, pp. 385-396. https://doi.org/10.1002/9781444303759.ch27.

Mørk, A., Embry, A.F. \& Weitschat, W. 1989: Triassic transgressiveregressive cycles in the Sverdrup Basin, Svalbard and the Barents Shelf. In Collinsen, J. (ed.): Correlation in hydrocarbon exploration, Norwegian Petroleum Society, Graham \& Trotman, London, pp. 113-130.

Nakrem, H.A., Orchard, M.J., Weitschat, W., Hounslow, M.W., Beatty, T.W. \& Mørk, A. 2008: Triassic conodonts from Svalbard and their Boreal correlations. Polar Research 27, 523-539. https://doi.org/10.1111/j.1751-8369.2008.00076.x.

Nichols, G. 1999: Sedimentology and stratigraphy, $2^{\text {nd }}$ edition. WileyBlackwell, Oxford, United Kingdom, 419 pp.

Rafaelsen, B., Elvebakk, G., Andreassen, K., Stemmerik, L., Colpaert, A. \& Samuelsberg, T.J. 2008: From detached to attached carbonate build-up complexes-3D seismic data from the Upper Palaeozoic, Finnmark Platform, southwestern Barents Sea. Sedimentary Geology 206, 17-32. https://doi.org/10.1016/j.sedgeo.2008.03.001.

Reid, C.M., James, N.P., Beauchamp, B. \& Kyser, T.K. 2007: Faunal turnover and changing oceanography: Late Palaeozoic warm to-cool water carbonates, Sverdrup Basin, Canadian Arctic Archipelago. Palaeogeography, Palaeoclimatology, Palaeoecology 249, 128-159. https://doi.org/10.1016/j.palaeo.2007.01.007.

Reijmer, J.J.G., Bauch, T. \& Schäfer, P. 2012: Carbonate facies patterns in surface sediments of upwelling and nonupwelling shelf environments (Panama, East Pacific). Sedimentology 59, 32-56. https://doi.org/10.1111/j.1365-3091.2010.01214.x.

Reymond, C. E., Zihrul, K.S., Halfar, J., Riegl, B., Humphreys, A. \& Westphal, H. 2016: Heterozoan carbonates from the equatorial rocky reefs of the Galápagos Archipelago. Sedimentology 63, 940958. https://doi.org/10.1111/sed.12244.

Rogers, J.P. \& Longman, M.W. 2001: An introduction to chert reservoirs of North America. American Association of Petroleum Geologists Bulletin 85, 1-5.

Scotese, C.R. \& Langford, R.P. 1995: Pangaea and the paleogeography of the Permian. In Scholle, P.A., Peryt, T.M. \& Ulmer-Scholle, D.S. (eds.): The Permian of northern Pangaea, Paleogeography, paleoclimates, stratigraphy - Volume I., Springer, Berlin, pp. 3-19. 
Seidler, L., Steel, R.J., Stemmerik, L. \& Surlyk, F. 2004: North Atlantic marine rifting in the Early Triassic: new evidence from East Greenland. Journal of the Geological Society 161, 583-592. https://doi.org/10.1144/0016-764903-063.

Steel, R.J. \& Worsley, D. 1984: Svalbard's post-Caledonian strata-an atlas of sedimentation patterns and paleogeographic evolution. In Spencer, A.M., Holter, E., Johnsen, S.O., Mørk, A., Nysæther, E., Songstad, P. \& Spinnangr, Å. (eds.): Petroleum Geology of the North European Margin, Norwegian Petroleum Society, Graham \& Trotman Ltd., London, pp. 109-135.

Stemmerik, L. \& Worsley, D. 1989: Late Palaeozoic sequence correlations, North Greenland, Svalbard and the Barents Shelf. In Collinsen, J. (ed.): Correlation in Hydrocarbon Exploration, Norwegian Petroleum Society, Graham \& Trotman, London, pp. 99-111.

Stemmerik, L. \& Worsley, D. 1995: Permian history of the Barents Shelf Area. In Scholle, P., Peryt, T. \& Ulmer-Scholle, D. (eds.): The Permian of Northern Pangaea, Sedimentary Basins and Economic Resources - Volume II., Springer-Verlag, Berlin, Heidelberg, pp. 81-97. https://doi.org/10.1007/978-3-642-78590-0_5.

Stemmerik, L. \& Worsley, D. 2005: 30 years on - Arctic Upper Palaeozoic stratigraphy, depositional evolution and hydrocarbon prospectivity. Norwegian Journal of Geology 85, 151-168.

Surdam, R.C. \& Stanley, K.O. 1981: Diagenesis and migration of hydrocarbons in the Monterey Formation, Pismo Syncline, California. In Garrison, R.E. \& Douglas, R.G. (eds.): The Monterey Formation and related siliceous rocks of California, Society of Economic Paleontologists and Mineralogists, Pacific Section, Los Angeles, pp. 317-327.

Wentworth, C.K. 1922: A scale of grade and class terms for clastic sediments. Journal of Geology 30, 377-392. https://doi.org/10.1086/622910.

Wignall, P.B., Morante, R. \& Newton, R. 1998: The Permo-Triassic transition in Spitsbergen: $\delta 13$ Corg chemostratigraphy, Fe and S geochemistry, facies, fauna and trace fossils. Geological Magazine 135, 47-62. https://doi.org/10.1017/S0016756897008121.

Ziegler, A., Hulver, M. \& Rowley, D. 1997: Permian World Topography and Climate. In Martini, I. (ed.): Late Glacial and Postglacial Environmental Changes, Quaternary, Carboniferous-Permian and Proterozoic, Oxford University Press, New York, Oxford, pp. 111146. 